\title{
Extraction Methods and Functional Properties of Protein from Arthospira platensis for Bioavailability of Algal Proteins
}

\author{
Mahmood Mahali ${ }^{1}$, Sibi G. ${ }^{2}$ \\ ${ }^{1}$ Department of Chemistry, Education Faculty, Jawzjan University, Sheberghan City, Afghanistan \\ ${ }^{2}$ Department of Biotechnology, Indian Academy Degree College-Autonomous, Bengaluru, India
}

Email address:

gsibii@gmail.com (Sibi G.)

To cite this article:

Mahmood Mahali, Sibi G. Extraction Methods and Functional Properties of Protein from Arthospira platensis for Bioavailability of Algal Proteins. International Journal of Pharmacy and Chemistry. Vol. 5, No. 2, 2019, pp. 20-25. doi: 10.11648/j.ijpc.20190502.12

Received: August 13, 2019; Accepted: August 28, 2019; Published: September 11, 2019

\begin{abstract}
Protein is one of the main nutrients that will be in short supply in the future. Alternative protein sources and production methods are required to fulfil the demand of protein requirements. Proteins from microalgae represent potential raw materials for the generation of protein based food ingredients. Arthospira platensis harbors high protein concentrations and one of the most important factors influencing successful extraction of protein is accessibility of the protein molecules. Process optimization and statistical analysis is necessary to maximize protein extraction. This study attempts to evaluate and compare various methods for their reliability in extracting microalgal proteins. Five different extraction methods namely alkali, enzymatic, thermal, microwave assisted and ultrasonic extraction were performed to obtain protein from A. platensis. Functional properties of the protein isolates were determined at various $\mathrm{pH}$ levels. Highest protein yield of $84 \%$ was obtained in ultrasound extraction. The lowest solubility of protein was found at $\mathrm{pH} 5.0(0.27 \%)$ and highest solubility of protein was obtained at $\mathrm{pH} 9.0(74.90 \%)$. Water holding capacity of protein isolates of $S$. platensis was in the range of $0.902-1.341$ $\mathrm{g}_{\text {water }} / \mathrm{g}_{\text {protein. }}$. The foaming capacity ranged from 19.37 to $41.28 \%$, with the lowest and maximum values obtained at $\mathrm{pH} 5.0$ and 3.0, respectively. Maximum value of foam stability at $\mathrm{pH} 5.0$ was $31.24 \%$ and this subsequently decreased when the $\mathrm{pH}$ increased. The results revealed that both microwave assisted and ultrasound extraction methods were found suitable to make bioavailability of algal proteins from Arthospira platensis.
\end{abstract}

Keywords: Protein Extraction, Arthospira, Microalgae, Microwave Assisted, Ultrasonic

\section{Introduction}

Protein is a very vital component of human nutrition. It is estimated that, nearly $25 \%$ of the world population lack suitable protein supply [1]. Protein is a substantial source of important amino acids and nitrogen. On commercial basis, food containing substantial amount of protein are gained from animal and plant sources and subsequently used as functional ingredients. Microbial proteins have been studied for likely incorporation into formulated foods, because of the limited availability and soaring costs of animal proteins [2].

Proteins from microalgae represent potential raw materials for the generation of protein based food ingredients having both techno- and biofunctional applications. Pre-treatments such as mechanical cell lysis, enzymatic, thermal, and chemical treatments result in improved component extraction by complete or partial degradation of the microalgal cell wall, thus, improving the accessibility of the intra-cellular components. Protein extraction methods used on algae to date are limited for commercial use due to concerns with upscaling. Conventional mechanical and enzymatic methods for protein extraction are laborious, time-consuming, and may require the use of solvents [3]. These methods may also affect the integrity of extracted algal proteins due to the release of proteases from cytosolic vacuoles [4]. Furthermore, these methods are also laborious and time consuming [5]. Extraction efficiency is affected by varying process parameters such as the solid to solvent ratio, solvent concentration and composition, extraction temperature, and time [6]. Improved extraction methods of cell disruption and 
extraction are therefore required. One of the most important factors influencing successful extraction of protein is accessibility of the protein molecules. The extraction of algal proteins is hindered, in part, due to high viscosity and ionic interactions arising from the presence of cell wall and intracellular polysaccharides [7]. Process optimization and statistical analysis is necessary to maximize protein extraction and determine the independent and interaction effects of various process parameters on the extraction yields.

Arthospira platensis is one of the more promising cyanobacteria, as it is rich in proteins, essential and nonessential amino acids, long-chain polyunsaturated fatty acids, vitamins, minerals and many phytonutrients. It harbors high protein concentrations, which can reach about $60-70 \%$ of its dry weight, depending upon the environmental conditions at which it is grown. This study attempts to evaluate and compare various methods for their reliability in extracting microalgal proteins. It dealt with process optimization for maximizing protein extraction from Arthospira platensis. Such knowledge is very useful in assessing the sustainability, scalability, and economic feasibility of the process.

\section{Materials and Methods}

\subsection{Protein Extraction Methods}

\subsubsection{Alkali Extraction}

Arthospira platensis biomass was subjected to pretreatment by high pressure homogenization. To the homogenized biomass, $1 \mathrm{M} \mathrm{NaOH}$ was added followed by centrifugation at $10000 \mathrm{rpm}$ for 15 mins. To the supernatant, either $1 \mathrm{M} \mathrm{HCl}$ or $1 \mathrm{M} \mathrm{HCOOH}$ was added and centrifuged again $10000 \mathrm{rpm}$ for 15 mins. The obtained pellet was used as estimate the protein content [8].

\subsubsection{Enzymatic Extraction}

One gram of A. platensis powder was dissolved in $10 \mathrm{~mL}$ of distilled water. The sample was adjusted to $\mathrm{pH} 5.0$ with buffer $\mathrm{NaH}_{2} \mathrm{PO}_{3}$ and incubated at $50^{\circ} \mathrm{C}$ with $1 \%(\mathrm{w} / \mathrm{w}$, protein basis) cellulase digested for $3 \mathrm{~h}$ [9]. After enzyme digestion, the mixture was centrifuged and the protein content of supernatant was estimated.

\subsubsection{Thermal Extraction}

For thermal pretreatment, $150 \mathrm{ml}$ of algal biomass was used. The algal biomass was pretreated in an incubator under continuous stirring at $95^{\circ} \mathrm{C}$ for 10 hours, and the hydrothermal pretreatment was performed in an autoclave at $120^{\circ} \mathrm{C}$ for 5 minutes. This was followed by filtering the algal biomass and estimation of protein.

\subsubsection{Microwave Assisted Extraction}

The microwave pretreatment was carried out in a household type microwave (LG, $2450 \mathrm{MHz}$ frequency). Extraction conditions were as follows: $1000 \mathrm{~W}$, liquid/solid ratio $(15 \mathrm{~mL} / 5.0 \mathrm{~g}$ of dry biomass), extraction time (3 $\mathrm{min}$.). After extraction, the mixture was centrifuged (5000 rpm for
$15 \mathrm{~min}$ ), and then the supernatant was gathered for the subsequent protein assay.

\subsubsection{Ultrasound Extraction}

Protein extraction from $A$. platensis was carried out by the method described by [10]. A. platensis was initially defatted using the method of the study [11]. After the defatting process, $1 \mathrm{~g}$ of sample was weighed into beakers followed by the addition of $15 \mathrm{ml}$ of distilled water. The beakers were mixed using a magnetic stirrer at room temperature for $60^{\circ} \mathrm{C}$ minutes. The samples were transferred into an ultrasound device and ultrasound extraction took place at $4 \pm 1{ }^{\circ} \mathrm{C}$ for 60 minutes. Samples were kept in a shaking water bath at 100 $\mathrm{rpm}$. This was followed by centrifugation at $5000 \mathrm{rpm} 4^{\circ} \mathrm{C}$ for $30 \mathrm{~min}$ and the supernatant was collected. $\mathrm{pH}$ of the supernatant was adjusted to 3, centrifuged again at $5000 \mathrm{rpm}$ $4^{\circ} \mathrm{C}$ for $30 \mathrm{~min}$ and the supernatant was discarded. The obtained pellet was used as estimate the protein content.

\subsection{Determination of Soluble Protein Yield}

To measure the soluble protein content for each experiment, the Folin phenol procedure was applied as described by [12]. The absorbance of protein in the algal extract was analyzed using a spectrophotometer at $680 \mathrm{~nm}$ and described as Cs. The yield of protein was estimated as follows:

$$
\mathrm{y}=\frac{\mathrm{Cs} \mathrm{V}}{\mathrm{m}} \mathrm{x} 100
$$

Where, y represents the soluble protein yield (\%), $\mathrm{C}_{\mathrm{s}}$ is the soluble protein concentration in the microalgae extract $(\mathrm{mg} / \mathrm{L}), \mathrm{V}$ is the volume of the microalgae extract $(\mathrm{L})$, and $\mathrm{m}$ represents the protein content of sample $(\mathrm{mg})$.

\subsection{Functional Properties of Isolated Protein}

\subsubsection{Protein Solubility}

Solubility of Arthospira protein was measured according to the study [13] with some modification. Protein suspension was added to distilled water $(2 \%, w / v)$, and adjusted at various $\mathrm{pH}$ values $(3,5,7,9$, and 11$)$ by using $0.5 \mathrm{~N} \mathrm{HCl}$ and $0.5 \mathrm{~N} \mathrm{NaOH}$. Centrifugation at $3000 \mathrm{rpm}$ for $20 \mathrm{~min}$ was then performed on the protein solution after it has been stirred for $60 \mathrm{~min}$ at room temperature. Then, the protein content in supernatant was measured using folin-phenol technique. Solubility was calculated as follows:

$$
\mathrm{S}=\frac{\mathrm{P}_{\text {Sup }}}{\mathrm{P}_{\text {Sam }}} \times 100
$$

Where, $\mathrm{S}$ representing protein solubility (\%) and $\mathrm{P}_{\text {sup }}, \mathrm{P}_{\text {sam }}$ representing content of protein in supernatant and sample $(\mathrm{mg} / \mathrm{mL})$, respectively.

\subsubsection{Water Holding Capacity}

To determine the water holding capacity, $0.1 \mathrm{~g}$ of protein isolate was dispersed in $10 \mathrm{ml}$ of deionized water and stirred for $5 \mathrm{~min}$. After stirring, the sample was allowed to 
stand/hydrate for $20 \mathrm{~min}$ and centrifuged at $5000 \mathrm{rpm}$ for 30 mins at room temperature. The supernatant was removed with a pipette, and tubes were reversed for $25 \mathrm{~min}$ to discard the residual liquid from the protein sample. The water holding capacity was described as $\mathrm{g}_{\text {water }} / \mathrm{g}_{\text {protein }}$ as follows [14].

$$
\text { Water holding capacity }=\frac{A-B}{C} \times 100
$$

Where, A representing mass of tube with the absorbed water and protein sample $(\mathrm{g}), \mathrm{B}$ representing mass of tube and protein sample $(\mathrm{g})$, and $\mathrm{C}$ is the mass of the algal protein sample (g).

\subsubsection{Foaming Properties}

Foaming properties of the algal protein in terms of foaming capacity (FC) and foam stability (FS) were measured according to [15]. Three grams of algal protein sample was added in $100 \mathrm{~mL}$ deionized water and the $\mathrm{pH}$ of mixture was adjusted to $3,5,7,9$ and 11. Protein solution was whipped at high speed in a mixer blender for $5 \mathrm{~min}$. The whole content was transported in a calibrated tube and foam volume was determined immediately to calculate the FC. The variation in volume of foam was estimated after $30 \mathrm{~min}$ from vigorous mixing at various $\mathrm{pH}(3,5,7,9$ and 11) to determine the FS. The FC (\%) and FS (\%) were calculated as follows:

$$
\mathrm{FC}=\frac{\mathrm{V}_{\mathrm{W} 2}-\mathrm{V}_{\mathrm{W} 1}}{\mathrm{~V}_{\mathrm{W} 1}} \times 100
$$

Water holding capacity $=\frac{\text { Foam volume after } 30 \mathrm{~min}}{\text { Initial foam volume }} \times 100$

Where, $\mathrm{V}_{\mathrm{W} 1}$ represents the volume before vigorous mixing $(\mathrm{mL})$ and $\mathrm{V}_{\mathrm{W} 2}$ represents the volume after vigorous mixing $(\mathrm{mL})$.

\subsection{Statistical Analysis}

All experiments were run in triplicates. Statistical analysis was conducted using analysis of variance to compare the influence of extraction methods on protein yield. Functional properties data were analyzed using SPSS Software. Statistical significance was tested at $\mathrm{P}<0.05$.

\section{Results and Discussion}

\subsection{Protein Yield}

Protein yield based on various extraction method were represented in figure 1 . Out of the five extraction methods evaluated, ultrasound, microwave, enzymatic and alkali mediated methods resulted in more than $75 \%$ protein yield. Highest protein yield of $84 \%$ was obtained in ultrasound extraction followed by enzymatic extraction method. Thermal extraction of algal protein was found low with $64 \%$ yield.

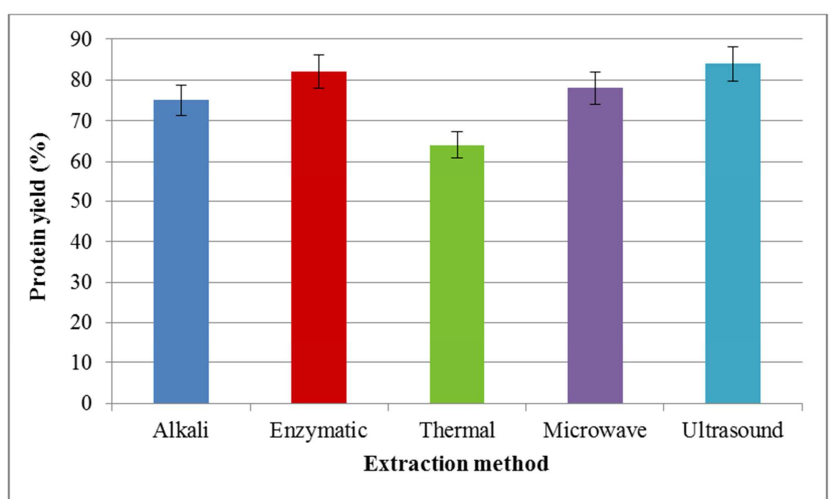

Figure 1. Protein yield from A. platensis under various extraction methods.

\subsection{Protein Solubility}

Protein solubility $\mathrm{pH}$ is a vital factor that has an important effect on protein solubility. Figure 2 shows the influence of $\mathrm{pH}$ on solubility of $A$. platensis protein isolate. Significant difference at $\mathrm{P}<0.05$ was obtained in the solubility from different $\mathrm{pH}$. The results showed two regions of solubility: at acidic $\mathrm{pH}$, which includes the point of isoelectric, and at alkaline $\mathrm{pH}$. The lowest solubility of protein was found at $\mathrm{pH}$ $5.0(0.27 \%)$ because the $\mathrm{pH}$ value was comparable to the protein isoelectric point $(\mathrm{pH} 4.5)$. Highest solubility of protein was obtained at $\mathrm{pH} 9.0(74.90 \%)$ of microwave assisted extraction followed by ultrasound extraction $(73.68 \%)$. At various $\mathrm{pH}$ values, the solubility may help as a useful indicator of the protein isolate performance in food industry as well as the amount of protein denaturation due to chemical or heat treatment. Most vegetable proteins have isoelectric $\mathrm{pH}$ values among 4.0 and 5.0, where the protein net charge reaches zero. Above $\mathrm{pH} 6.5$, all vegetable proteins have solubilities of $>70 \%$ [16] as was observed in this research. The trend of the results agreed with that obtained by [17] for cottonseed meal protein isolate.

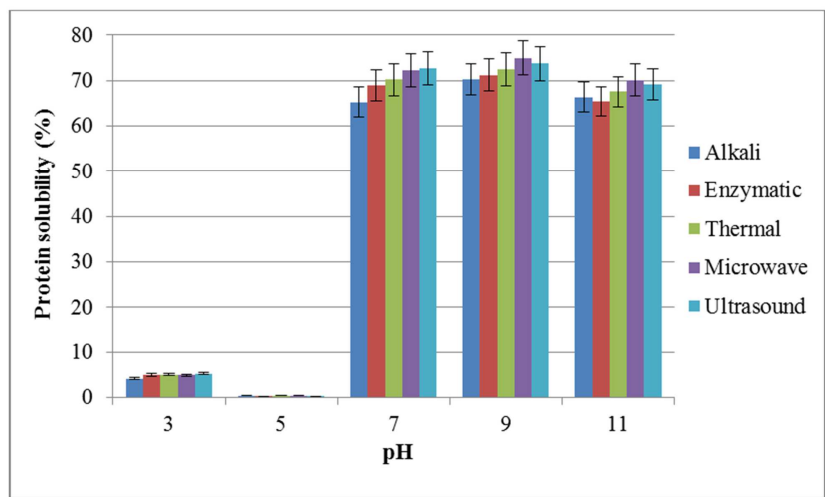

Figure 2. Solubility (\%) of A. platensis protein at various pH levels.

\subsection{Water Holding Capacity}

Water holding capacity is an important functional property of proteins. It measures the ability of proteins to absorb water against gravity. Water holding capacity of protein isolates of A. platensis was in the range of $0.902-1.341 \mathrm{~g}_{\text {water }} / \mathrm{g}_{\text {protein }}$. 


\subsection{Foaming Capacity}

The foaming capacity is a vital parameter in food products [18]. The foam stability and foaming capacity of protein isolate from $A$. platensis at different $\mathrm{pH}$ are presented in figures 3 and 4. Significant difference at $\mathrm{P}<0.05$ was obtained in the foam stability and foaming capacity from different $\mathrm{pH}$. The foaming capacity ranged from 19.37 to $41.28 \%$, with the lowest and maximum values obtained at $\mathrm{pH}$ 5.0 and 3.0, respectively. Highest foam capacity of was observed in microwave assisted protein extract followed by thermal extraction of protein isolate. At $\mathrm{pH} 3$ and 7, higher percentage of foam capacity was determined. Both the $\mathrm{pH}$ and extraction method had influenced the foam capacity. In other words, $37.69 \%$ of foaming capacity at $\mathrm{pH} 7$ and $22.63 \%$ at $\mathrm{pH} 5$ of thermal extraction, $41.28 \%$ at $\mathrm{pH} 3$ and $22.44 \%$ at $\mathrm{pH} 9$ of microwave assisted extraction, $26.13 \%$ at pH 11 of alkali extracted protein were found out.

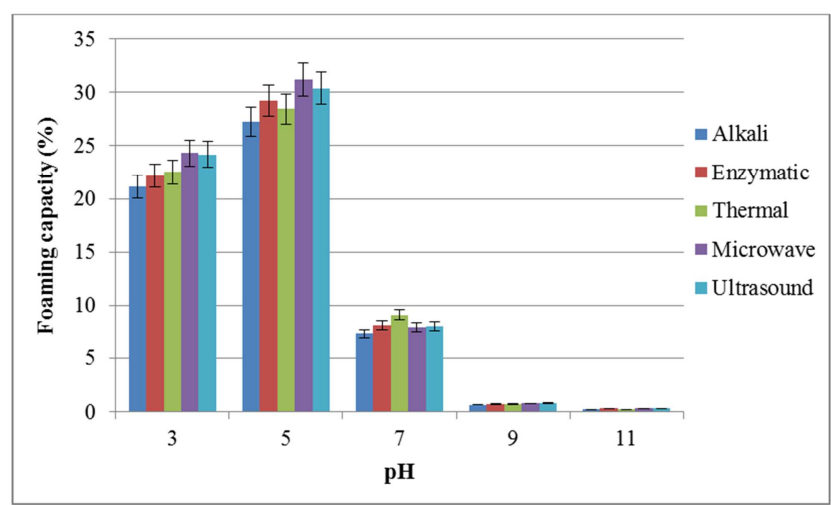

Figure 3. Foaming capacity (\%) of A. platensis protein at various pH levels.

\subsection{Foam Stability}

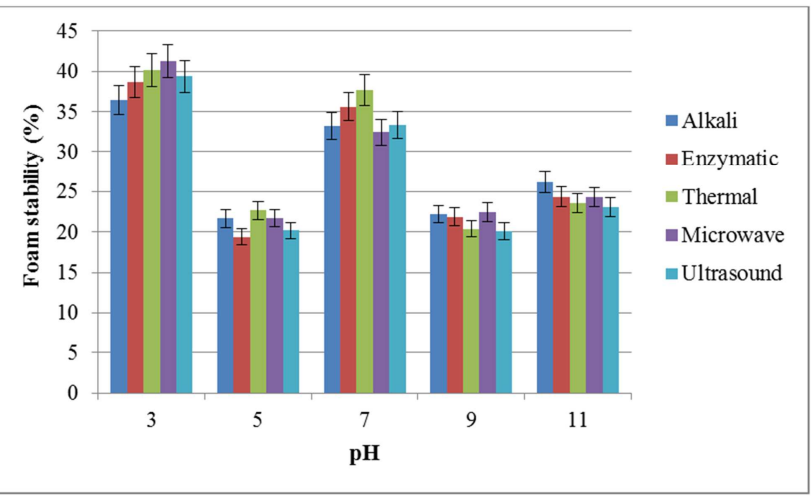

Figure 4. Foam stability (\%) of A. platensis protein at various $p H$ levels.

Regarding foam stability, the results showed that the maximum value at $\mathrm{pH} 5.0$ was $31.24 \%$ and this subsequently decreased when the $\mathrm{pH}$ increased. The least value of foam stability was $0.20 \%$ at $\mathrm{pH} 11$. Microwave assisted protein extraction had highest foam stability followed by ultrasound extraction. In general, foam stability was higher at acidic $\mathrm{pH}$ levels and this could be attributed to the protein adsorption and viscoelasticity at an air-water interface in maximal closeness to isoelectric $\mathrm{pH}$. Additionally, this may well be due to a possible low net charge near the isoelectric $\mathrm{pH}$ of the protein [19]. These results corroborate with those obtained for protein isolate from safflower and lentil respectively $[20,21]$.

If the quality and quantity of protein extracted is consistent and the samples are rich in protein diversity, relevant biological conclusions can be drawn from the data under study. It is suggested that the procedures described in this study may be widely applicable for protein extraction from other microalgae too. Extracting the protein fraction from the rest of the algal matrix makes the end product becomes more nutrient dense [22].

Microwave treatment is one of the most commonly used methods for solid-liquid extraction due to its power, convenience, and reasonable cost. The microwave-induced dipole rotation of molecules, and the migration of ions that enhance the penetration of solvent in to matrix, disrupts the cell wall and releases the intracellular product, allowing for the extraction of different components [23]. The main parameters in microwave assisted extraction are microwave power, time, algae type and temperature [24, 25]. Commercial microwave ovens typically use a frequency of $2.45 \mathrm{GHz}$, which corresponds to a wavelength of $12.24 \mathrm{~cm}$ [26].

Ultrasound can be effectively used to increase the yield and rate of mass transfer in several solid-liquid extraction processes. The extraction mechanism involves two types of physical phenomena: diffusion through the cell walls and washing out (raising) the cell contents once the wall are broken. Both phenomena are significantly affected by ultrasound irradiation [27]. Cavitation phenomena lead to high shear forces in the media. The implosion of cavitation bubbles on a product's surface results in micro-jetting which generates several effects such as surface peeling, erosion and particle breakdown. Additionally, implosion of cavitation bubbles in a liquid media leads to macro-turbulences and to a micro mixing. This leads to a decreasing in extraction temperature and minimal chemical usage, thereby increasing extraction rate and yield [28]. Depending on the frequency, ultrasound can be categorized into three main classes: these include low, high, and diagnostic ultrasonic at respective frequency ranges of $20-100 \mathrm{kHz}, 100-1000 \mathrm{kHz}$, and $1-500$ $\mathrm{MHz}$ [29]. Power ultrasound $(20-100 \mathrm{kHz})$ is widely applied in the food industry for various extraction processes including protein extraction [30].

The fact that proteins in water obtain net positive or negative charges when adjusted to extremely acid or alkaline conditions, respectively, can be the basis for their isolation. This is since the strong repulsions caused by like charges favour protein solubilization, whereupon non-soluble matter can be removed. Hence the alkali method resulted in lowest protein yield in this study.

\section{Conclusion}

To make a protein recovery process economically feasible and easy to apply in industry, a simplistic approach with a minimum amount of low energy steps 
would be beneficial. Bearing this goal in mind, the aim of the present study was to develop basic settings for a relatively simple protein extraction protocol for $A$. platensis. The findings of this study recommend the microwave assisted and ultrasound extraction mediated protein extraction from Arthospira platensis. Further, selection of appropriate extraction method while extracting protein from microalgae is important to minimize the cost and maximize the protein yield. Such knowledge is very useful in assessing the sustainability, scalability, and economic feasibility of the protein yield from microalgae.

\section{References}

[1] Azam, S., Khan, Z., Ahmad, B., Khan, I., Ali, J. (2014). Production of single cell protein from orange peels using Aspergillus niger and Saccharomyces cerevisiae. Global J. Biotechnol. Biochem. 9 (1): 14-18.

[2] Claver, I. P., Zhou, H. (2005). Enzymatic hydrolysis of defatted wheat germ by proteases and the effect on the functional properties of resulting protein hydrolysates. J. Food Biochem. 29 (1): 13-26.

[3] Kadam, S. U., Tiwari, B. K., O’Donnell, C. P. (2013). Application of novel extraction technologies for bioactives from marine algae. J. Agric. Food Chem. 61: 4667-4675.

[4] Geneva, V., Galutzov, B., Teissie, J. (2003). High yield electroextraction of proteins from yeast by a flow process. Anal. Biochem. 315: 77-84.

[5] Kadam, S. U., Alvarez, C., Tiwari, B. K., O’Donnell, C. P. (2017). Extraction and characterization of protein from irish brown seaweed Ascophyllum nodosum. Food Res. Int. 99: 1021-1027.

[6] Setyaningsih, W., Duros, E., Palma, M., Barroso, C. G. (2016). Optimization of the ultrasound-assisted extraction of melatonin from red rice (Oryza sativa) grains through a response surface methodology. Applied Acoustics. 103: 129-135.

[7] Joubert, Y., Fleurence, J. (2008). Simultaneous extraction of protein and DNA by an enzymatic treatment of the cell wall of Palmaria palmata (Rhodophyta). J. Appl. Phycol. 20: 55-61.

[8] Parimi, N. S., Singh, M., Kastner, J. R., Das, K. C., Forsberg, L. S., Azadi, P. (2015). Optimization of protein extraction from Spirulina platensis to generate a potential co-product and a biofuel feedstock with reduced nitrogen content. Front. Energy Res. 3: 30.

[9] Zhang, R., Chen, J., Zhang, X. (2018). Extraction of intracellular protein from Chlorella pyrenoidosa using a combination of ethanol soaking, enzyme digest, ultrasonication and homogenization techniques. Bioresour. Technol., 247: 267-272.

[10] Benelhadj, S., Gharsallaoui, A., Degraeve, P., Attia, H., Ghorbel, D. (2016). Effect of $\mathrm{pH}$ on the functional properties of Arthrospira (Spirulina) platensis protein isolate. Food Chem. 194: 1056-1063.

[11] Stone, A. K., Karalash A., Tyler R. T., Warkentin T. D., Nickerson M. T. (2015). Functional attributes of pea protein isolates prepared using different extraction methods and cultivars. Food Res. Int. 76: 31-38.

[12] Ledoux, M., Lamy, F. (1986). Determination of proteins and sulfobetaine with the folinphenol reagent. Anal. Biochem., 157 (1): 28-31.

[13] Achouri, A., Nail, V., Boye, J. I. (2012). Sesame protein isolate: Fractionation, secondary structure and functional properties. Food Res. Int. 46 (1): 360-369.

[14] Shchekoldina, T., Aider, M. (2014). Production of low chlorogenic and caffeic acid containing sunflower meal protein isolate and its use in functional wheat bread making. J. Food Sci. Technol., 51 (10): 2331-2343.

[15] Fekria, A. M., Isam, A. M., Suha, O. A., Elfadil, E. B. (2012). Nutritional and functional characterization of defatted seed cake flour of two Sudanese groundnut (Arachis hypogaea) cultivars. Int. Food Res. J., 19 (2): 629-637.

[16] Bora, P. S. (2002). Functional properties of native and succinylated lentil (Lens culinaris) globulins. Food Chem. 77 (2): 171-176.

[17] Ma, M., Ren, Y., Xie, W., Zhou, D., Tang, S., Kuang, M., Du, S. K. (2018). Physicochemical and functional properties of protein isolate obtained from cottonseed meal. Food Chem., 240: 856-862.

[18] Singh, P., Kumar, R., Sabapathy, S. N., Bawa, A. S. (2008). Functional and edible uses of soy proteins products. Comprehensive Reviews in Food Science and Food Safety, 7 (1): 14-28.

[19] Lawal, O. S., Adebowale, K. O., Adebowale, Y. A. (2007). Functional properties of native and chemically modified protein concentrates from bambarra groundnut. Food Res. Int. 40 (8): 1003-1011.

[20] Ulloa, J. A., Rosas-Ulloa, P., Ulloa-Rangel, B. E. (2011). Physicochemical and functional properties of a protein isolate produced from safflower (Carthamus tinctorius L.) meal by ultrafiltration. J. Sci. Food Agri., 91 (3): 572-577.

[21] Jarpa-Parra, M., Bamdad, F., Wang, Y., Tian, Z., Temelli, F., Han, J., Chen, L. (2014). Optimization of lentil protein extraction and the influence of process $\mathrm{pH}$ on protein structure and functionality. LWT - Food Sci. Technol., 57 (2): 461-469.

[22] Hou, X., Hansen, J. H., Bjerre, A. B. (2015). Integrated bioethanol and protein production from brown seaweed Laminaria digitata. Bioresour. Technol 197: 310-317.

[23] Li, J., Zu, Y. G., Fu, Y. J., Yang, Y. C., Li, S. M., Li, Z. N., Wink, M. (2010). Optimization of microwave-assisted extraction of triterpene saponins from defatted residue of yellow horn (Xanthoceras sorbifolia Bunge.) kernel and evaluation of its antioxidant activity. Innovative Food Sci. Emerg. Technol. 11: 637-643.

[24] Pasquet, V., Cherouvrier, J. R., Farhat, F., Thiry, V., Piot, J. M., Berard, J. B, Kaas, R., Serive, B., Patrice, T., Cadoret, J. P., Picot, L., (2011). Study on the microalgal pigments extraction process: Performance of microwave assisted extraction. Proc. Biochem., 46: 59-67.

[25] Maki-Arvela, P., Hachemi, I., Murzin, D. Y., (2014). Comparative study of the extraction methods for recovery of carotenoids from algae: extraction kinetics and effect of different extraction parameters. J. Chem. Technol. Biotechnol., 89: 1607-1626. 
[26] Kappe, CO. (2004). Controlled microwave heating in modern organic synthesis, Angew. Chem., Int. Ed. Engl. 43: 62506284.

[27] Vinatoru, M. (2001). An overview of the ultrasonically assisted extraction of bioactive principles from herbs. Ultrasonics Sonochemistry. 8: 303-313.

[28] Virot, M., Tomao, V., Le Bourvellec, C., Renard, C. M., Chemat, F. (2010). Towards the industrial production of antioxidants from food processing byproducts with ultrasound-assisted extraction. Ultrasonics Sonochemistry, 17 (6): 1066-1074.
[29] Pilli, S., Bhunia, B., Yan, S., LeBlanc, R. J., Tyagi, R. D., Surampalli, R. Y. (2011). Ultrasonic pretreatment of sludge: A review. Ultrasonics Sonochemistry, 18 (1): 1-18.

[30] Pradal, D., Vauchel, P., Decossin, S., Dhulster, P., Dimitrov, K. (2016). Kinetics of ultrasound-assisted extraction of antioxidant polyphenols from food byproducts: Extraction and energy consumption optimization. Ultrasonics Sonochemistry, 32: $137-146$. 